\title{
Peer Mentoring Module: The Effect of an Intervention of Academic Mentoring Program towards Motivation and Self-esteem among Foundation Students in Malaysia
}

\author{
Haizan Taha ${ }^{1, *}$, Fauziah Hanim ${ }^{2}$, Mastura Johar ${ }^{1}$, Mardian Shah ${ }^{1}$ \\ ${ }^{1}$ Department of Social Science, Universiti Tenaga Nasional, Malaysia \\ ${ }^{2}$ Department of Guidance Counselling, University Education Sultan Idris Shah, Malaysia
}

Copyright (C) 2015 Horizon Research Publishing All rights reserved.

\begin{abstract}
Academic mentoring program between peer mentors and mentees is believed to be as part of the guidance and counselling practice to enhance the development of education field. This program practiced Peer Mentoring Module (PMM) for peer mentors with skills namely: interpersonal relationship, communication, motivation, empathy and emotional stability. The purpose of this research is to identify the effectiveness of PMM on the treatment of students' motivation and self-esteem among foundation students in a private University in Malaysia. Forty subjects (mentees) with CGPA $<2.00$ points were tutored by forty trained mentors. A pretest-posttest control research design was utilized to look at the difference of the level of motivation and self-esteem of the students (mentees) with low achievement (CGPA below 2.00 points). Two types of instruments are used in this study; Rosenberg Self-Esteem (RSE) and Achievement Goal Questionnaire (AGQ). The subjects were examined at week one for pre-test and post-test at week ten. Statistical analysis included (group x time) measures t-test to determine between and within group mean differences. The overall findings support the hypothesis that PMM intervention to train peer mentors in Mentoring Program shows positive effects on increasing the level of motivation and general self-esteem of mentees. After 10 weeks during the post-test, there was statistically improved in RSE and AGQ scores $(p<0.05)$. The research outcome may help researchers to proof that PMM through academic mentoring program can increase the attitude and confidence of the mentees. Therefore, a more positive learning perspective among the low achievers will be one of the important aspects in implementing the guidance and counselling practice in academic mentoring.
\end{abstract}

Keywords Academic Mentoring; Peer Mentoring Module (PMM); Motivation, Self-esteem and Guidance \& Counselling.

\section{Introduction}

The concept of mentoring has been used to describe the master craftsman, who not only trains his apprentice in the art of his trade, but also ensures he grows up to follow certain values perceived by society to be important, Maynard and Furlong [9]. So there is a long standing definition, which encompasses the older experienced individual passing down his knowledge of how the task is done and how to work with other people, Clutterbuck [4]. Furthermore, Anderson and Shannon [1] defined mentoring as a nurturing process in which a more skilled and a more experienced person, serving as a role model, teaches, sponsors, encourages, counsels and befriends a less skilled or a less experienced person for the purpose of promoting the latter's personal and/or personal development. Mentoring functions are carried out within the context of an ongoing, caring relationship between the mentor and associate. The real strength of mentoring comes from the social relationship based connections, focused towards desired outcomes, meeting the needs of both the mentor and protégé (mentee).

Mentoring relationship between peers can be based on trust and empathy. In Model of Youth Mentoring by DuBois and Karcher [6] it shows that this kind of special relationship on trust and empathy will lead to social-emotional, identity, and cognitive development. This model assumed that positive result can be achieved through grade performance, emotional stability and good behavior. Therefore, the Peer Mentoring Module (PMM) is developed to train future peer mentors with soft skills that will make them more confidence, more caring and make them realize that the more knowledge they share, the more knowledge they will gain. The PMM is built systematically and provides skills namely: interpersonal relationship, communication, motivation, empathy and emotional stability for peer mentors to give opinions and constructive responses within group cohesiveness. As a result, the existence of mentoring relationship will be very strong among them and their protégé. Figure 1 below refers the PMM which is based from the Model of Youth Mentoring by DuBois and Karcher [6]. 


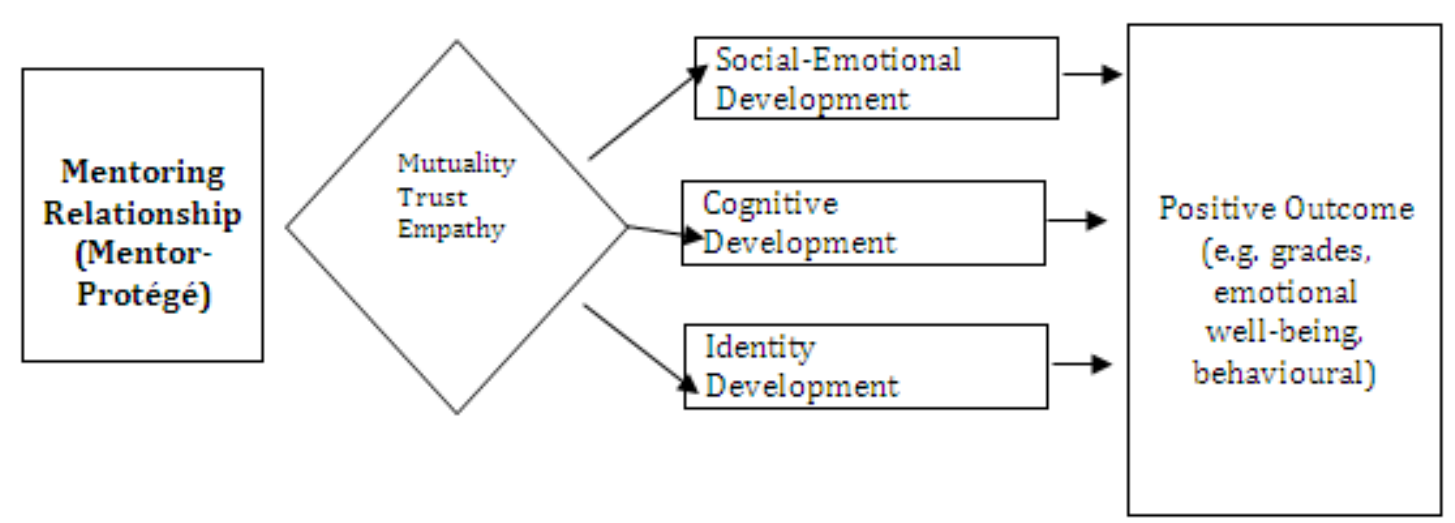

Sources: Model of Youth Mentoring: David L. DuBois, Michael J. Karcher. (2005). Handbook of Youth Mentoring: Sage Publication, Inc. California, USA, (3), 30-38.

Figure 1. Peer Mentor Module based on the Model of Youth Mentoring

The Peer Mentoring Module (PMM) is also developed with various soft skills related to Big Five Personality Dimensions consists of agreeableness, conscientiousness, extraversion, openness and neuroticism by Oliver and Sanjay [10] along with Person Centered Theory including aspects of unconditional positive regard, self-actualization, active listening, empathy and genuine by Rogers [12]. In addition, Kolb Model of Experiential Learning by Wolf and Kolb [13] is used to relate the activities regarding the PMM with types of experience faced by both mentor and protégé (mentee) during their weekly academic mentoring sessions.

Academic mentoring program is a part of guidance and counselling practice to increase the level of self-esteem and motivation among students and to enhance the development of education field. Research done by Othman [11] and Zahara [14] shows that positive self esteem is related to good academic achievement. According to Brown and Alexander [3] self esteem is a way of how individuals foresee and evaluate themselves. It concludes the fact that characteristics can be learned and it comes from life experiences with comments and observations from others. Furthermore, from Azizi Yahya et al. [2] higher level of self esteem comes from positive evaluation of oneself. According to Deci \& Ryan [5] achievement goals are those learning perspectives that guide a student's learning motivation. Originally two types of motivation were described as intrinsic motivation, which reflects an internal drive by the individual to learn or obtain knowledge, and extrinsic motivation in which the individual is driven by the need for external gratification or reward Deci \& Ryan [5].

\section{Methodology}

Validity of content has been tested towards the Peer Mentoring Module (PMM) on statements or items regarding activities from the module in paper presented at UPSI-UPI conference at Shah Alam by Haizan and Fauziah [7]. The outcome shows that maximum coefficient value of content validity made by 5 experts from local universities is 0.87 $(87 \%)$ and total coefficient validity is $0.84(84 \%)$. Therefore, a study has been carried out to look at the effectiveness of the module on helping the underachievers.

Two groups (Control - 20 mentees; and Treatment -20 mentees) of foundation student (mentee) in University Tenaga Nasional (UNITEN) consists of 40 people with Cumulative Grade Point Average (CGPA) $<2.00$ points has been tutored by 40 trained mentors (Treatment Group - 20 mentors trained with Peer Mentoring Module/PMM; \& Control Group - 20 mentors trained with an established Peer Guidance Module/PGM) for 10 sessions/weeks. The mentees went through tutoring sessions for 2 repeated subjects; Physics 1 (PHYF 115) and Calculus 1 (MATF 115). Two instruments; Rosenberg Self Esteem (RSE) and Achievement Goal Questionnaire (AGQ) are used to measure the level of self-esteem and motivation of mentees on week 1 (Pre-Test) and week 10 (Post-Test). The RSE survey contains 10 items ( 5 positive and 5 negative statements) aimed to measure individual general self-esteem and the AGQ contains 12 items (3 performance approach, 3 performance avoidance, 3 mastery avoidance and 3 mastery performance) aimed to measure individual academic achievement motivation.

\section{Results}

A pretest-posttest control research design (Control - PGM; Treatment - PMM) was utilized to look at the difference of the level of motivation and self-esteem of the students (mentees) with low achievement (CGPA below 2.00 points). The Engineering students were categorized specifically by their major namely: 25\% Electrical Electronic (AE), 30\% Mechanical (AM), 20\% Power (AP) and 25\% Civil (AS) as in Figure 2 for Engineering program and Figure 3 for distribution of gender for each group. 




Figure 2. Frequency distribution of Engineering Students



Figure 3. Distribution of Male and Female for Control \& Treatment

\subsection{Self-Esteem (RSE)}

The results for self-esteem and motivation obtained from the preliminary analysis of the frequency distribution are shown in Table 1 and 2. To evaluate the impact of the intervention on subjects' self-esteem scores for both groups, the descriptive statistics test was conducted. There were statistically significant increase in the scores on the groups at week one (Pre-test) to week ten (Post-test). Levene's test on homogeneity of variance towards Pre-test, showed that significant level $\mathrm{p}>0.5(\mathrm{p}=.303)$ with the mean difference of treatment group $(\mathrm{M}=12.90, \mathrm{SD}=1.17)$, and control group $(\mathrm{M}=12.35, \mathrm{SD}=1.76)$. While it is reported that, Levene's test on homogeneity of variance towards Post-test, showed that significant level $\mathrm{p}<0.5(\mathrm{p}=.003)$, with the mean difference of treatment group $(\mathrm{M}=20.00, \mathrm{SD}=3.28)$, and control group $(\mathrm{M}=18.55, \mathrm{SD}=2.52)$. Table 1 presents the results clearly.
Table 1. Descriptive Statistics Outcome on Pre-test and Post-test for Self-Esteem

\begin{tabular}{|c|c|c|c|c|c|c|c|}
\hline \multirow{2}{*}{ Variables } & Group & N & Mean & SD & \multicolumn{4}{|c|}{$\begin{array}{c}\text { Homogeneity of } \\
\text { variance } \\
\end{array}$} & & & & df1 & sig \\
\hline Pretest & Treatment & 20 & 12.90 & 1.17 & 2 & 37 & .303 \\
\hline & Control & 20 & 12.35 & 1.76 & & & \\
\hline & Total & $\mathbf{4 0}$ & & & & & \\
\hline Posttest & Treatment & 20 & 20.00 & 3.28 & 2 & 37 & $.003^{*}$ \\
\hline & Control & 20 & 18.55 & 2.52 & & & \\
\hline & Total & $\mathbf{4 0}$ & & & & & \\
\hline
\end{tabular}

Note:* The mean difference is significant at the .05 level.

In addition, the findings on impact strength subject within-group towards self-esteem post-test; $\mathrm{F}(2,37)=$ $55.324, \mathrm{p}<.05$, eta square $=.660$. Because of $\mathrm{p}$ value is less than .05 , then the main effect for the group is statistically significant. Eta square value is $66 \%$, which indicates a major impact that shows from variability in self-esteem that relates with the intervention group. Table 2 shows the statistical findings on self-esteem for pre-test and post-test within-group.

Table 2. Statistical Findings for Pre-test and Post-test on Self-Esteem

\begin{tabular}{|c|c|c|c|c|c|}
\hline Variables & Statistic & df & F & Sig. & Eta Sq. \\
\hline Pre-Test & $\begin{array}{c}\text { Between } \\
\text { Group }\end{array}$ & 2 & .691 & .505 & .024 \\
\hline Self-Esteem & $\begin{array}{c}\text { Within } \\
\text { Group }\end{array}$ & 37 & & & \\
\hline Post-Test & $\begin{array}{c}\text { Total } \\
\text { Between } \\
\text { Group }\end{array}$ & 29 & 55.324 & .000 & .660 \\
\hline Self-Esteem & $\begin{array}{c}\text { Within } \\
\text { Group }\end{array}$ & 37 & & & \\
\hline & Total & 39 & & & \\
\hline
\end{tabular}

\subsection{Motivation (AGQ)}

Table 3. Descriptive Statistics Outcome on Pre-test and Post-test for Motivation

\begin{tabular}{|c|c|c|c|c|c|c|c|}
\hline \multirow{2}{*}{ Variables } & Group & $\mathrm{N}$ & Mean & $\mathrm{SD}$ & \multicolumn{3}{|c|}{$\begin{array}{c}\text { Homogeneity of } \\
\text { variance }\end{array}$} \\
\hline Pretest & Treatment & 20 & 8.58 & 1.38 & 2 & 37 & .130 \\
\hline & Control & 20 & 7.33 & .873 & & & \\
\hline & Total & $\mathbf{4 0}$ & & & & & \\
\hline Posttest & Treatment & 20 & 13.56 & 1.15 & 2 & 37 & $.000^{*}$ \\
\hline & Control & 20 & 12.61 & 1.33 & & & \\
\hline & Total & $\mathbf{4 0}$ & & & & & \\
\hline
\end{tabular}

Note: * The mean difference is significant at the .05 level.

To evaluate the impact of the intervention on subjects' motivation scores, the descriptive statistics was conducted. There were statistically significant increase in the scores on the groups at week one (Pre-test) to week ten (Post-test). Levene's test on homogeneity of variance towards Pre-test, showed that significant level $p>0.5(p=.130)$ with the mean 
difference of treatment group $(\mathrm{M}=8.58, \mathrm{SD}=1.38)$, and control group $(\mathrm{M}=7.33, \mathrm{SD}=.873)$. While it is reported that, Levene's test on homogeneity of variance towards Post-test, showed that significant level $\mathrm{p}<0.5(\mathrm{p}=.000)$, with the mean difference of treatment group $(\mathrm{M}=13.56, \mathrm{SD}$ $=1.15)$, and control group $(\mathrm{M}=12.61, \mathrm{SD}=1.33)$. Table 3 present the results clearly.

In addition, the findings on impact strength subject within-group towards motivation post-test; $F(2,37)=$ $96.144, p<.05$, eta square $=.771$. Because of $p$ value is less than .05 , then the main effect for the group is statistically significant. Eta square value is $77 \%$, which indicates a major impact that shows from variability in motivation that relates with the intervention group. Table 4 shows the statistical findings on motivation for pre-test and post-test within-group.

Table 4. Statistical Findings for Pre-test and Post-test on Motivation

\begin{tabular}{|c|c|c|c|c|c|}
\hline Variables & Statistic & $\mathrm{df}$ & F & Sig. & Eta Sq. \\
\hline Pre-Test & $\begin{array}{c}\text { Between } \\
\text { Group }\end{array}$ & 2 & 12.971 & .000 & .313 \\
\hline \multirow[t]{2}{*}{ Motivation } & $\begin{array}{l}\text { Within } \\
\text { Group }\end{array}$ & 37 & & & \\
\hline & Total & 39 & & & \\
\hline Post-Test & $\begin{array}{c}\text { Between } \\
\text { Group }\end{array}$ & 2 & 96.144 & .000 & .771 \\
\hline \multirow[t]{2}{*}{ Motivation } & $\begin{array}{l}\text { Within } \\
\text { Group }\end{array}$ & 37 & & & \\
\hline & Total & 39 & & & \\
\hline
\end{tabular}

\section{Conclusions}

The overall findings support the hypothesis that Peer Mentoring Module (PMM) intervention to train peer mentors in academic mentoring program shows positive effects on increasing the level of motivation and general self-esteem of mentees for both treatment and control groups, and this supported by past research done by Haizan \& Fauziah [8] on CGPA and self-esteem of the underachievers. After 10 weeks during the post-test, there was statistically improved in RSE and AGQ scores $(p<0.05)$ for both groups. The findings clearly stated that both level self-esteem and motivation of the protégé (mentees) or the underachievers have increased tremendously for treatment group (mentors trained by using PMM); same as control group (mentors trained by using an established Peer Guidance Module).

The results suggest that the PMM would be best practiced on every trimester for foundation program. Hence, with good academic achievement and higher level of self-esteem and motivation, the foundation students especially the underachievers will be well prepared to start their degree in engineering program. The research outcome may help researchers to proof that PMM through academic mentoring program can increase the attitude and confidence of the mentees. Therefore, a more positive learning perspective among the low achievers will be one of the important aspects in implementing the guidance and counselling practice in the academic mentoring.

\section{REFERENCES}

[1] Anderson EM, Shannon AL. (1988). Toward a conceptualization of mentoring.JTeacher Educ;39(1):38-42

[2] Azizi Yahaya, Jaafar Sidek Latif, Shahrin Hashim \& Yusof Boon (2005). Alam Remaja. Bentong: PTS Publication \& Distributions Sdn. Bhd.

[3] Brown,L., \& Alexander, J. (1991). Self-Esteem Index (SEI). Austin, Texas: Pro-ed Publisher

[4] Clutterbuck, D. (1991). Everyone Needs a Mentor: Fostering Talents at Work. Chartered Institute of Personnel \& Development, London.

[5] Deci, E. L., \& Ryan, R. M. (1985). Intrinsic Motivation and Self-determination in human behavior. New York: Plenum.

[6] David L. DuBois \& Michael J. Karcher. (2005). Handbook of Youth Mentoring. Sage Publication, Inc. California, USA.

[7] Haizan M. Taha dan Fauziah Hanim A. Jalal. (2012). Validity of Peer Mentoring Module in Mentoring Program with Underachievers. Conference proceedings at International Conference UPSI-UPI, Concorde Hotel, Shah Alam, Selangor.

[8] Haizan M. Taha dan Fauziah Hanim A. Jalal. (2012). "The Effectiveness of Mentoring Through Peer Mentor Module Towards Cumulative Grade Point Average (CGPA) and Self Esteem of the Underachievers." Conference proceedings at National Research \& Innovation Conference For Graduate Students in Social Sciences'12, Mahkota Hotel, Melaka.

[9] Maynard, T. \& Furlong, J. (1993). Learning to teach and models of mentoring. In McIntyre, D., Hagger, H. \& Wilkin, M. (Eds.) Mentoring: Perspectives on School-Based Teacher Education. London, Kogan Page.

[10] Oliver PJ, Sanjay S. (1999). The big five trait taxonomy: History, measurement and theoreticalperspectives. In: Pervin LA, John OP, eds. Handbook of personality: Theory and research, 2nd ed. New York: Guilford.

[11] Othman Md. Johan. (1995). Kesan Konsep Kendiri Terhadap Tingkahlaku Murid-murid. Tesis Ijazah Kedoktoran yang tidak diterbitkan, Fakulti Pendidikan, UKM.

[12] Rogers, C. (1959). A theory of therapy, personality and interpersonal relationships as developed in the client-centered framework. In Koch, S. (Ed.). Psychology: A study of a science. Vol. III. Formulations of the person and the social context. New York: McGraw Hill.

[13] Wolf, D.M. and Kolb, D.A. (1984). Career Development, Personal Growth and Experiential Learning, in Organisational Psychology. Prentice-Hall, New Jersey.

[14] Zahara Aziz. (2000). Beberapa Strategi Pengajaran Berpusatkan Pelajar \& Kemahiran Berfikir Secara Kritis \& Kreatif di Sekolah Menengah di Semenanjung Malaysia. International Conference on Teaching \& Learning in $21^{\text {st }}$ Century, Putrajaya, 4-5 Nov. 2000. 